\title{
ESTIMATED EXPOSURE OF SPINE SURGEONS TO RADIATION
}

\author{
ESTIMATIVA DA EXPOSIÇÃO DE CIRURGIÕES DE COLUNA VERTEBRAL À RADIAÇÃO
}

ESTIMATIVA DE LA EXPOSICIÓN DE CIRUJANOS DE COLUMNA VERTEBRAL A LA RADIACIÓN

\author{
Carlos Alexandre Botelho do Amaral, ${ }^{1}$ Ricardo Alves Andrade, ${ }^{1}$ Pedro José Labronicl ${ }^{1,2}$ \\ 1. Hospital Santa Teresa, Orthopedics and Traumatology Service, Spine Group, Petrópolis, RJ, Brazil. \\ 2. Universidade Federal Fluminense, Niterói, RJ, Brazil.
}

\begin{abstract}
Objective: To estimate the amount of radiation received and accumulated in the bodies of two surgeons, one being the responsible surgeon and the other the assistant, performing spine surgery procedures over a period of 25 years. Methods: Seventy-two spinal surgeries were performed during a seven-month period and the radiation loads were measured in both surgeons. The measurement of radiation was captured in fluoroscopy in anteroposterior and lateral incidences. The surgeon and the assistant used two dosimeters, one in the cervical region protecting the thyroid and the other on the lead apron in the genital region. The radioactive loads were measured in millisieverts and the accumulated charges were recorded monthly in both regions of the body in the two surgeons for seven months and the means for the work periods $(1,5,10,15,20$ and 25 years) were estimated. Results: It was observed that in the surgeon the average accumulated radiation loads were $131.9 \%$ and $176.92 \%$ higher than those of the assistant in the cervical and genital regions, respectively. Conclusion: While the use of X-rays is indispensable in routine orthopedic surgery, we have to consider the development of techniques of protection, rigor and discipline in the use of safety materials for surgeons. Preventive exposure reduction measures such as using thyroid protection equipment and turning the head away from the patient during fluoroscopy, among others, should be mandatory to promote less radiation exposure. Level of evidence II; Comparative prospective study.
\end{abstract}

Keywords: Orthopedic Surgeons; Spine; Radiation Exposure; Personal Protective Equipment.

\section{RESUMO}

Objetivo: Estimar a quantidade de radiação recebida e acumulada no corpo de dois cirurgiões, durante período de 25 anos de trabalho, sendo um o cirurgião responsável e outro, assistente, nos procedimentos de cirurgia da coluna vertebral. Métodos: Foram realizadas 72 cirurgias de coluna vertebral em um período de sete meses, e as cargas de radiação foram medidas nos dois cirurgiões. A medição da radiação foi captada em fluoroscópio nas incidências anteroposterior e de perfil. O cirurgião e o auxiliar utilizaram dois dosímetros, sendo um na região cervical protegendo a tireoide e outro sobre o avental de chumbo, na região genital. As cargas radioativas foram medidas em milisievert e as cargas acumuladas foram registradas mensalmente em ambas as regiões do corpo nos dois cirurgiões, durante sete meses, foram estimadas as médias no período (1, 5, 10, 15, 20 e 25 anos) de trabalho. Resultados: Observou-se que no cirurgião as médias das cargas de radiação acumulada foram 131,9\% e 176,92\% superiores às do assistente nas regiões cervical e genital, respectivamente. Conclusão: Enquanto o uso dos raios X for indispensável na rotina da cirurgia ortopédica, há de se considerar o desenvolvimento de técnicas de proteção, rigor e disciplina no uso materiais de segurança para os cirurgiões. Medidas preventivas de redução da exposição, como uso de equipamento para proteção da tireoide e girar a cabeça para se afastar do paciente durante a fluoroscopia, entre outras, devem ser obrigatórias para promover menor exposição à radiação. Nível de evidência II; Estudo prospectivo comparativo.

Descritores: Cirurgiões Ortopédicos; Coluna Vertebral; Exposição à Radiação; Equipamentos de Proteção Pessoal.

\section{RESUMEN}

Objetivo: Estimar la cantidad de radiación recibida y acumulada en el cuerpo de dos cirujanos, durante 25 años de trabajo, siendo uno el cirujano responsable y el otro, asistente, en los procedimientos de cirugía de columna vertebral. Métodos: Se realizaron 72 cirugías de columna vertebral en un período de siete meses, y las cargas de radiación fueron medidas en los dos cirujanos. La medición de la radiación fue captada en fluoroscopio en las incidencias anteroposterior y de perfil. El cirujano y el auxiliar usaron dos dosímetros, siendo uno en la región cervical protegiendo la tiroides y otro sobre el delantal de plomo, en la región genital. Las cargas radiactivas se midieron en milisievert, y las cargas acumuladas se registraron mensualmente en ambas regiones del cuerpo, en los dos cirujanos, durante siete meses, y se estimaron los promedios durante el período (1, 5, 10, 15, 20 y 25 años) de trabajo. Resultados: Se observó que en el cirujano los promedios de las cargas de radiación acumulada fueron de 131,9\% y 176,92\% superiores a las del asistente en las regiones cenvical y genital, respectivamente. Conclusión: Mientras el uso de rayos X sea indispensable en la rutina de la cirugía ortopédica, hay que considerar el desarrollo de técnicas de protección, rigor y disciplina en el uso de materiales de seguridad para los cirujanos. Las medidas preventivas de reducción de la exposición, como uso de equipamiento para protección de la tiroides y girar la cabeza para alejarse del paciente durante la fluoroscopia, entre otras, deben ser obligatorias para promover menor exposición a la radiación. Nivel de evidencia Il; Estudio prospectivo comparativo.

Descriptores: Cirujanos Ortopédicos; Columna Vertebral; Exposición a la Radiación; Equipos de Protección Personal.

Study conducted at the Hospital Santa Teresa, Orthopedics and Traumatology Service, Spine Group, Petrópolis, RJ, Brazil.

Correspondence: Pedro José Labronici. Av. Roberto Silveira, 187, apto 601, Petrópolis, RJ, Brasil. 25685-040. plabronici@globo.com 


\section{INTRODUCTION}

Fluoroscopy is an X-ray imaging technique widely used in orthopedics to obtain real-time images of the skeletal structures to confirm the reduction of fractures and guide the placement of implants during surgical procedures. ${ }^{1-3}$ Intraoperative fluoroscopic images are extremely important in diagnosis and aid in the treatment of orthopedic pathologies. Spine surgery in particular is highly dependent on fluoroscopy for locating vertebral levels, guiding pedicle screw placement and evaluating instrumentation in reconstruction procedures. ${ }^{4-8}$

The use of fluoroscopy in spine surgeries, in which higher doses of radiation are used to achieve a suitable image compared to those used in other parts of the body, has increased markedly in recent years. One study ${ }^{8}$ concluded that doses of radiation during spine surgery procedures are ten to twelve times higher than during non-spinal procedures.

However, the exposure of patients, surgeons and nursing professionals to radiation in the operating room in order to obtain intraoperative images generates concern in the medical and scientific community, ${ }^{4,5,9,10}$ since it is known that such radiation can be a determinant in provoking hair loss, skin burns, nausea, cataracts, and stochastic effects, i.e., carcinogenesis and teratogenesis. ${ }^{11}$ The organs sensitive to radiation include gonads, bone marrow, breasts, corneas, the gastrointestinal tract, lungs and thyroid glands, ${ }^{12}$ and therefore the concern of surgeons over the effects of exposure during radiation, mainly on such sensitive organs., ${ }^{3,5,13-16}$ There is no dose of radiation, known to be safe but low doses of radiation during fluoroscopy in surgeries can accumulate over the life of the surgeon and warrant attention. ${ }^{17-19}$

The objective of this study is to estimate the quantity of radiation received and accumulated in the body, in two surgeons, one the lead surgeon and the other the assistant, over a period of 25 years of work.

\section{METHODS}

During the period between February and September 2018, 72 spine surgeries were performed at the Hospital Santa Teresa, Petrópolis/RJ. The surgeries were performed over a period of seven months, and the radiation loads were measured in the two surgeons, one being the surgeon and the other the assistant. The criteria for inclusion in the sample were surgeries for fractures, disc degeneration or herniation in patients above 18 years of age who required fluoroscopy during the surgical procedure. The surgeons who participated in the study signed the Informed Consent Form. The exclusion criteria were patients with neoplasms, infections and angular deformities.

The measurement of the radiation was captured by the anteroposterior and lateral fluoroscope. Each of the professionals, the surgeon and the assistant, used two dosimeters (PRO RAD-Radioprotection, approved by the CNEN/IRD under code 010.02 TL- Certificate 102/2010) affixed to the cervical and genital regions, on the thyroid protector and lead apron, respectively, in order to measure the radioactive load received in these regions during the surgical procedures. The radioactive loads were measured in millisieverts (mSv - unit of measurement of the impact of radiation on human beings), and the accumulated loads were recorded monthly in the region of the body, in both surgeons over a period of seven months and estimated for the periods of $1,5,10,15,20$, and 25 years of work. The devices used the thermoluminescent dosimetry technique and recorded the result of the measurement when the load was less than $0.2 \mathrm{mSv}$. For the calculations, the measurement was considered equal to the midpoint of this class, $0.1 \mathrm{mSv}$, as recommended by the statistical analysis methodology. The surgical procedure time was also measured and recorded for later calculation of the radioactive exposure load per unit of time.

The data collected during the surgeries and the radioactive loads measured by the dosimeters were loaded into a Microsoft Excel 2013 electronic spreadsheet, thus constituting the research database. Excel was also used for graph construction, and the other statistical analyse were conducted using the Statistical Package for the Social Sciences (SPSS), version 22.0, with a focus on calculation of the descriptive statistics (minimum, maximum, mean, median, standard deviation, accumulated values and coefficient of variation (CV)). The distribution variance of a variable was considered low if $\mathrm{CV}<0.20$, moderate if $0.20 \leq \mathrm{CV} \leq 0.40$, and high if $\mathrm{CV} \geq 0.40$. The relationship between the accumulated load and the duration of the surgery was analyzed calculating the accumulated load by unit of time.

\section{RESULTS}

Table 1 shows the main statistics of the surgeries performed by the two surgeons in the seven months of observation, by month and in total. From the CVs of the duration of the surgeries, all of them < 0.40 , it was concluded that the duration of the surgeries in all months and in total had high variability. In total, the surgeries performed by the surgeons had durations ranging from 0.42 hours (25 minutes) to 7.42 hours (seven hours and 42 minutes), with a mean of $3.76 \pm$ 2.03 hours of duration ( 3 hours and 46 minutes). The median was 3.86 hours ( 3 hours and 52 minutes). That is, it is estimated that $50 \%$ of the surgeries performed by the surgeons lasted less than 3.86 hours and $50 \%$ of the surgeries lasted more than 3.86 hours. Therefore, at the end of seven months, the surgeons had dedicated 270.5 hours to these surgical procedures.

As shown in Table 1, the number of surgeries performed by the surgeons ranged from five to fourteen surgeries per month, during the period observed. Table 2 shows the main statistics about the number of surgeries performed monthly by the surgeons. The mean is $10.3 \pm 3.7$ surgeries per month, resulting in a CV of 0.36 , showing that the monthly number of surgeries had moderate variance. The median was 11 surgeries.

We were able to obtain predictions of the radiation accumulated by the two surgeons during the seven-month period from the dosimeters placed in their cervical and genital regions and to produce the statistics displayed in Table 3. The assistant's radiation load in the cervical region after one hour of surgery is $20.5 \%$ greater than the radiation accumulated in the genital region. For the surgeon, the difference between the radiation loads accumulated in the cervical and genital regions is much smaller, on the order of $0.9 \%$. Comparing the

Table 1. Key statistics from surgeries performed by the two surgeons in the seven months of observation and in total.

\begin{tabular}{c|c|c|c|c|c|c|c|c}
\hline \multirow{2}{*}{ Statistics } & \multicolumn{7}{|c|}{ Months } & \multirow{2}{*}{ Total } \\
\cline { 2 - 8 } & $\mathbf{1}$ & $\mathbf{2}$ & $\mathbf{3}$ & $\mathbf{4}$ & $\mathbf{5}$ & $\mathbf{6}$ & $\mathbf{7}$ & \\
\hline Number of surgeries & 7 & 15 & 12 & 8 & 14 & 11 & 5 & 72 \\
\hline Minimum duration (h) & 1.17 & 0.90 & 0.58 & 0.50 & 0.42 & 0.83 & 1.33 & 0.42 \\
\hline Maximum duration (h) & 7.08 & 7.17 & 6.33 & 6.33 & 7.18 & 7.42 & 5.57 & 7.42 \\
\hline Mean surgical duration (h) & 4.24 & 4.06 & 3.68 & 3.59 & 3.51 & 3.86 & 3.10 & 3.76 \\
\hline \pm surgical duration (h) & 2.06 & 2.14 & 1.66 & 2.21 & 2.22 & 2.29 & 2.03 & 2.03 \\
\hline $\begin{array}{c}\text { Median surgical duration } \\
\text { (h) }\end{array}$ & 4.17 & 3.92 & 3.77 & 4.07 & 3.25 & 4.58 & 1.92 & 3.86 \\
\hline CV of surgical duration & 0.49 & 0.53 & 0.45 & 0.61 & 0.63 & 0.59 & 0.65 & 0.54 \\
\hline Total surgical time (h) & 29.67 & 60.85 & 44.13 & 28.75 & 49.17 & 42.42 & 15.52 & 270.50 \\
\hline $\mathrm{h}$ (hour), CV (coefficient of variance).
\end{tabular}

Table 2. Key statistics of the number of surgeries performed by the surgeons monthly.

\begin{tabular}{c|c}
\hline Statistic & Value \\
\hline Total surgeries & 72 \\
\hline Mean number of surgeries & 10.3 \\
\hline Median number of surgeries & 11 \\
\hline \pm the number of surgeries & 3.7 \\
\hline CV of the number of surgeries & 0.6 \\
\hline
\end{tabular}

\pm (standard deviation); CV (coefficient of variance) 
radiation loads of the assistant and the surgeon, the mean radiation load accumulated in the cervical region of the surgeon is $131.9 \%$ higher than the mean radiation load accumulated in the cervical region of the assistant and the mean radiation load accumulated in the genital region of the surgeon is $176.92 \%$ higher than the mean radiation load accumulated in the genital region of the assistant.

The accumulated loads are small for a one-hour period but considering the fixed routine of the surgeons over the seven months of the study, it is possible to predict the radiation load accumulated over an estimated period (1, 5, 10, 15, 20, and 25 years of work). The results of these forecasts are described in Table 4 and Figure 1. In the graph, it is possible to see the differences in accumulated radiation loads found in this study. The accumulated loads are much higher for the surgeon, especially in the long term. The radiation loads accumulated in the cervical and genital regions are practically the same for the surgeon, while, for the assistant physician, the radiation loads accumulated in the cervical region are slightly higher than those accumulated in the genital region.

Table 3. Mean radiation loads accumulated in the routine of two surgeons per hour of surgery and per 10 hours of surgery.

\begin{tabular}{c|c|c|c|c}
\hline \multirow{2}{*}{ Means } & \multicolumn{3}{|c}{ Accumulated radiation load (mSv) } \\
\cline { 2 - 5 } & \multicolumn{2}{|c}{ Assistant } & \multicolumn{2}{c}{ Surgeon } \\
\cline { 2 - 5 } & $\begin{array}{c}\text { Cervical } \\
\text { region }\end{array}$ & $\begin{array}{c}\text { Pelvic } \\
\text { region }\end{array}$ & $\begin{array}{c}\text { Cervical } \\
\text { region }\end{array}$ & $\begin{array}{c}\text { Pelvic } \\
\text { region }\end{array}$ \\
\hline 1 hour of surgery & 0.0047 & 0.0039 & 0.0109 & 0.0108 \\
\hline 10 hours of surgery & 0.047 & 0.039 & 0.109 & 0.108 \\
\hline mSv (millisievert)
\end{tabular}

Table 4. Radiation load accumulated in routine exposure of the two surgeons, observed in seven months of work and forecast for the period estimated $(1,5,10,15,20$ and 25 years of work).

\begin{tabular}{c|c|c|c|c|c|c}
\hline \multirow{2}{*}{ Estimates } & \multirow{2}{*}{$\begin{array}{c}\text { Number of } \\
\text { surgeries }\end{array}$} & Total exposure & \multicolumn{3}{|c}{ Accumulate radiological load (mSv) } \\
\cline { 4 - 7 } & & & \multicolumn{2}{|c|}{ Assistant } & \multicolumn{2}{c}{ Surgeon } \\
\cline { 4 - 7 } & & $\begin{array}{c}\text { Cervical } \\
\text { region }\end{array}$ & $\begin{array}{c}\text { Pelvic } \\
\text { region }\end{array}$ & $\begin{array}{c}\text { Cervical } \\
\text { region }\end{array}$ & $\begin{array}{c}\text { Pelvic } \\
\text { region }\end{array}$ \\
\hline 7 months & 72 & 270.5 & 1.26 & 1.05 & 2.94 & 2.92 \\
\hline 1 year & 123 & 463.7 & 2.16 & 1.80 & 5.04 & 5.01 \\
\hline 5 years & 617 & 2319 & 10.80 & 9.00 & 25.20 & 25.03 \\
\hline 10 years & 1234 & 4637 & 21.60 & 18.00 & 50.40 & 50.06 \\
\hline 15 years & 1851 & 6956 & 32.40 & 27.00 & 75.60 & 75.09 \\
\hline 20 years & 2469 & 9274 & 43.20 & 36.00 & 100.80 & 100.11 \\
\hline 25 years & 3086 & 11593 & 54.00 & 45.00 & 126.00 & 125.14 \\
\hline $\mathrm{h}$ (hour); mSv (millisievert). & & & & &
\end{tabular}

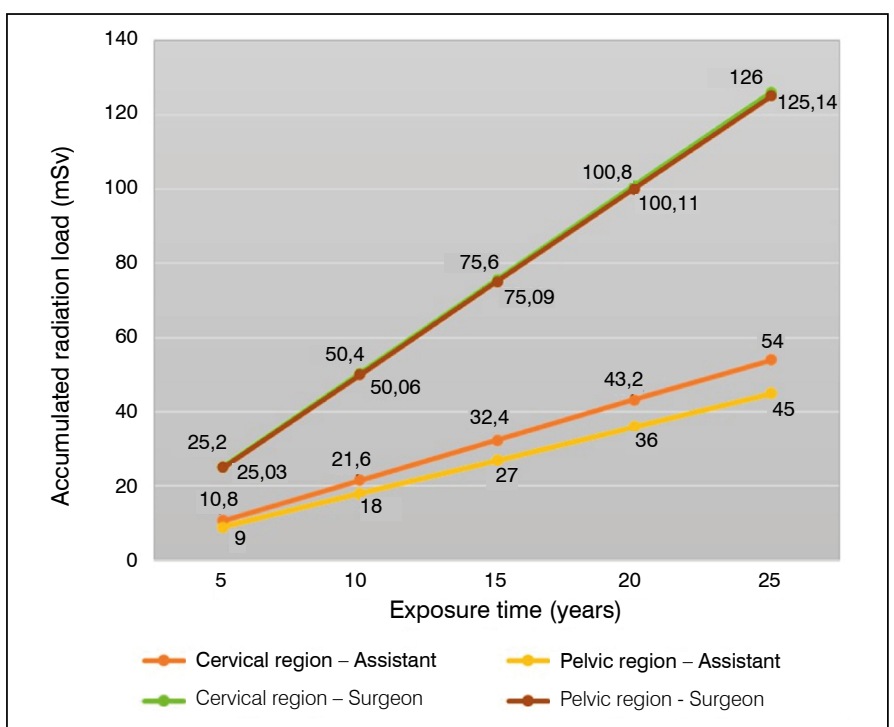

Figure 1. Predicted radiation load accumulated in the routine of two surgeons by exposure time.

\section{DISCUSSION}

Exposure to the radiation emitted during intraoperative fluoroscopy is a concern for the medical and scientific community, especially in spine surgeries in which relatively higher doses of radiation have been used to achieve suitable images than in other parts of the body. Considering the importance of evaluations and data related to this subject, the objective of this study was to estimate the radiation load accumulated by the surgeon in an estimated period $(1,5,10,15,20$ and 25 years of work), alerting spine surgeons to protect themselves and, consequently, avoid diseases.

There is great concern about the radiation dose that surgeons receive during their careers. Exposure to radiation in medicine is not benign and the cost of obtaining images can be causing cancer in between $0.6 \%$ and $3 \%$ of the population. ${ }^{20}$ A Scoliosis Research Society report highlighted this fact, demonstrating the existence of a surge in thyroid cancer among surgeons. ${ }^{21}$

How much radiation is $1 \mathrm{mSv}$ and what is the associated risk of developing malignity? The International Commission on Radiological Protection recommends that exposure to radiation be limited to $20 \mathrm{mSv}$ per year. On the other hand, there are no specific recommendations for limiting radiation exposure for surgeons in the operating room. ${ }^{22}$

One study ${ }^{23}$ using a dosimeter, reported that the main surgeon received $4.2 \%$ of the radiation emitted while the assistant received $1.3 \%$. The present study also observed a higher radiation load absorbed by the lead surgeon. Also in the study mentioned above, ${ }^{23}$ when the surgeons used protective equipment, such as lead apron, goggles and thyroid protector, the dose of radiation emitted was reduced from $94 \%$ to $98 \%$. Some authors ${ }^{7,24}$ pay attention to the cumulative impact on surgeons of a certain number of procedures over time or during their careers.

In our study, considering the data observed during the seven-month period, the monthly and accumulated exposure times, it was possible to predict the accumulated load (after 1, 5, 10, 15, 20, and 25 years of work). With the results, it was demonstrated that even though the monthly loads were small, the radiation accumulated over the long term reaches significant numbers. This study also showed that accumulated loads were higher for the lead surgeon, both in the cervical and genital regions. No difference was observed for the lead surgeon between the accumulated loads in the two regions. For the assistant surgeon, the loads were greater in the cervical than in the genital region, but less than those of the lead surgeon. Another study ${ }^{25}$ observed that the chest region was more exposed to radiation when compared to the gonads. In our study, the mean radiation load accumulated in the cervical region was $131.9 \%$ higher in the lead surgeon than in the assistant. The mean radiation load accumulated in the genital region of the surgeon was $176.9 \%$ higher than in the genital region of the assistant.

A study ${ }^{26}$ demonstrated that in spine surgeries, the surgeon, using fluoroscopy and working next to the X-ray tube in a lateral position is exposed to six to twenty times more radiation (depending on the location of the dosimeter) than the assistant. However, when possible, surgeons should distance themselves from the patient and the X-ray tube to minimize radiation exposure. Urakov ${ }^{27}$ showed that the current safe distance for unprotected parts of the body seems to be $4.2 \mathrm{~m}$ in front of the tube and $2.4 \mathrm{~m}$ behind it. Contrary to what was believed, at a distance of $1.8 \mathrm{~m}$ from the X-ray tube, even though behind it, the amount of radiation present is still 3 to 4 times greater than imagined. Considering the annual dose limits for specific organs suggested by the National Council on Radiation Protection, intraoperative use of fluoroscopy should be limited to 1,839 to 8,078 minutes of exposure for the chest, 3,723 to 5,489 minutes for the gonads, 4,949 to 11,549 minutes for the eyes, and 6,406 to 19.194 minutes for the thyroid. In terms of the acceptable radiation exposure for the hands, the data indicated that the limit was approximately 1,325 minutes. ${ }^{28}$

This study, following the routine of the surgeons over seven months, shows significant estimates of radiation load accumulated by the two surgeons and the estimates of the hours of exposure during a 
25-year career. The estimates are 695,580 minutes of exposure in an average of 11 surgeries per month over 25 years of work. Therefore, the surgeons would accumulate 27,825 minutes per year, which according to the National Council on Radiation Protection, can be critical for certain organs.

This study draws the attention of the community of spine surgeons and of the medical community in general to an important issue the radiation load accumulated in the body of the spine surgeon, acquired by exposure to fluoroscopy $\mathrm{X}$-rays in their daily routine at the surgery center. The study showed that the accumulated loads are small for the period of one month but based on the principle that the radiation load received is cumulative and considering that the routines of the surgeons observed in this study are consistent, the proportional forecasts of long-term accumulated load (1, 5, 10, 15, 20 and 25 years of work) yields numbers that warrant attention.

The evaluations performed show a forecast of $126 \mathrm{mSv}$ accumulated from exposure of the cervical region and $125.14 \mathrm{mSv}$ accumulated from exposure of the genital region of the lead surgeon after 25 years of work, and $54.00 \mathrm{mSv}$ accumulated in the cervical region and 45.00 $\mathrm{mSv}$ accumulated in the genital region of the assistant surgeon after 25 years of work. It is worth mentioning that the results found are minimal estimates, since they are based on the routine of surgeons in only one institution and it is known that it is difficult for a surgeon to have their routine concentrated in only one institution. Therefore, the real radioactive loads could be up to three times the values found in this study.

This study has some limitations. The estimates were calculated based on a fixed number of surgeries performed by the professionals in their routine at only one surgical center where they operate.
For this reason, the statistics presented in this study may be underestimated, since professionals typically work at more than one institution. However, even if underestimated, the results presented are meaningful estimates that give an idea of the significance of the accumulated radiation. We believe that this number would be enough to alert spine surgeons to protect themselves and thereby prevent future health issues. Although the accumulated radiation estimate has been analyzed in various spinal pathologies, we do not believe it is a limitation of the study, as we try to be as faithful as possible to the reality of everyday medical practice.

\section{CONCLUSION}

The exposure of surgeons to radiation in the operating room calls attention to the important precaution of increased distance from the source and protection during fluoroscopy. While the use of this source of X-rays is indispensable to the orthopedic surgical routine, it is necessary to consider the development of protection techniques, rigor and discipline in the use of safety materials for surgeons. Preventative measures to reduce exposure, such as the use of thyroid protection equipment, turning the head away from the patient during fluoroscopy use, among others, should be mandatory to promote less exposure.

All authors declare no potential conflict of interest related to this article.

CONTRIBUTION OF THE AUTHORS: Each author made significant individual contributions to this manuscript. CABA: lead surgeon, design of the research project, writing, review; RAA: assistant surgeon, writing, data collection, review; PJL: design of the research project, statistical analysis, writing, review.

\section{REFERENCES}

1. Zwingmann J, Konrad G, Kotter E, Südkamp NP, Oberst M. Computer-navigated iliosacral screw insertion reduces malposition rate and radiation exposure. Clin Orthop Relat Res. 2009:467(7):1833-8. doi: 10.1007/s11999-008-0632-6.

2. Li YY, Hsu RW, Cheng CC, Huang TJ. Minimally invasive vertebroplasty managed by a two C-arm fluoroscopic technique. Minim Invasive Ther Allied Technol. 2007:16(6):350-4. doi: 10.1080/13645700701627654.

3. Giordano BD, Ryder S, Baumhauer JF, DiGiovanni BF. Exposure to direct and scatter radiation with use of mini-c-arm fluoroscopy. J Bone Joint Surg Am. 2007;89(5):948-52. doi: 10.2106/JBJS.F.00733

4. Haque MU, Shufflebarger HL, O'Brien M, Macagno A. Radiation exposure during pedicle screw placement in adolescent idiopathic scoliosis: is fluoroscopy safe? Spine (Phila Pa 1976). 2006:31(21):2516-20 doi: 10.1097/01.brs.0000238675.91612.2

5. Theocharopoulos N, Perisinakis K, Damilakis J, Papadokostakis G, Hadjipavlou A, Gourtsoyiannis N. Occupational exposure from common fluoroscopic projections used in orthopaedic surgery. J Bone Joint Surg Am. 2003;85(9):1698-703. doi: 10.2106/00004623200309000-00007.

6. Singer G. Occupational radiation exposure to the surgeon. J Am Acad Orthop Surg 2005:13(1):69-76 doi: 10.5435/00124635-200501000-00009.

7. Bindal RK, Glaze S, Ognoskie M, Tunner V, Malone R, Ghosh S. Surgeon and patient radiation exposure in minimally invasive transforaminal lumbar interbody fusion. J Neurosurg Spine. 2008:9(6):570-3. doi: 10.3171/SPI.2008.4.08182.

8. Jones DP, Robertson PA, Lunt B, Jackson SA. Radiation exposure during fluoroscopically assisted pedicle screw insertion in the lumbar spine. Spine (Phila Pa 1976). 2000;25(12):153841. doi: 10.1097/00007632-200006150-00013.

9. Singer G. Radiation exposure to the hands from mini C-arm fluoroscopy. J Hand Surg Am 2005;30(4):795-7. doi: 10.1016/j.jhsa.2005.01.007.

10. Tsalafoutas IA, Tsapaki V, Kaliakmanis A, Pneumaticos S, Tsoronis F, Koulentianos ED, et al. Estimation of radiation doses to patients and surgeons from various fluoroscopically guided orthopaedic surgeries. Radiat Prot Dosimetry. 2008;128(1):112-9. doi: 10.1093/ $\mathrm{rpd} / \mathrm{ncm} 234$

11. Blakely EA. Biological effects of cosmic radiation: deterministic and stochastic. Health Phys. 2000;79(5):495-506. doi: 10.1097/00004032-200011000-00006.

12. Biswas D, Bible JE, Bohan M, Simpson AK, Whang PG, Grauer JN. Radiation exposure from musculoskeletal computerized tomographic scans. J Bone Joint Surg Am. 2009;91(8):18829. doi: 10.2106/JBJS.H.01199

13. Giordano BD, Rechtine GR 2nd, Morgan TL. Minimally invasive surgery and radiation exposure. J Neurosurg Spine. 2009;11(3):375-6. doi: 10.3171/2009.2.spine09181.

14. Giordano BD, Baumhauer JF, Morgan TL, Rechtine GR 2nd. Patient and surgeon radiation exposure: comparison of standard and mini-C-arm fluroscopy. J Bone Joint Surg Am. 2009;91(2):297-304. doi: 10.2106/JBJS.H.00407.
15. Shoaib A, Rethnam U, Bansal R, De A, Makwana N. A comparison of radiation exposure with the conventional versus mini $\mathrm{C}$ arm in orthopedic extremity surgery. Foot Ankle Int 2008:29(1):58-61. doi: 10.3113/FAl.2008.0058.

16. Giordano BD, Baumhauer JF, Morgan TL, Rechtine GR. Cervical spine imaging using standard C-arm fluoroscopy: patient and surgeon exposure to ionizing radiation. Spine (Phila Pa 1976). 2008;33(18):1970-6. doi: 10.1097/BRS.0b013e31817e69b7.

17. Mathews JD, Forsythe AV, Brady Z, Butler MW, Goergen SK, Byrnes GB, et al. Cancer risk in 680000 people exposed to computed tomography scans in childhood or adolescence: data link age study of 11 million Australians. BMJ. 2013:346:1-18. doi: 10.1136/bmj.f2360.

18. Donya M, Radford M, EIGuindy A, Firmin D, Yacoub MH. Radiation in medicine: origins, risks and aspirations. Glob Cardiol Sci Pract. 2014:2014(4):437-48. doi: 10.5339/gcsp.2014.57.

19. Kadhim M, Salomaa S, Wright E, Hildebrandt G, Belyakov OV, Prise KM, et al. Non-targeted effects of ionising radiation - implications for low dose risk. Mutat Res. 2013;752(2):84-98. doi: 10.1016/j.mrrev.2012.12.001.

20. Gonzalez AB, Darby S. Risk of cancer from diagnostic X-rays: estimates for the UK and 14 other countries. Lancet. 2004;363(9406):345-51. doi: 10.1016/S0140-6736(04)15433-0.

21. Wagner TA, Lai SM, Asher MA, editors. SRS Surgeon members' risk for thyroid cancer: is it increased? Spine. 2006. Meeting Abstracts: Scoliosis Research Society. $41^{\text {st }}$ Annual Meeting. Paper 40

22. Mendelsohn D, Strelzow J, Dea N, Ford NL, Batke J, Pennington A, et al. Patient and surgeon radiation exposure during spinal instrumentation using intraoperative CT-based navigation. Spine J. 2016;16(3):343-54. doi: 10.1016/j.spinee.2015.11.020.

23. Mulconrey DS. Fluoroscopic radiation exposure in spinal surgery: in vivo evaluation for operating room personnel. Clin Spine Surg. 2016;29(7):E331-5. doi: 10.1097/ BSD.0b013e31828673c1.

24. Ahn Y, Kim CH, Lee JH, Lee SH, Kim JS. Radiation exposure to the surgeon during percutaneous endoscopic lumbar discectomy: a prospective study. Spine (Phila Pa 1976). 2013:38(7):617-25. doi: 10.1097/BRS.0b013e318275ca58.

25. Lee K, Lee KM, Park MS, Lee B, Kwon DG, Chung CY. Measurements of surgeons' exposure to ionizing radiation dose during intraoperative use of $C$-arm fluoroscopy. Spine. 2012:37(14):1240-4. doi: 10.1097/BRS.0b013e31824589d5.

26. Nelson EM, Monazzam SM, Kim KD, Seibert JA, Klineberg EO. Intraoperative fluoroscopy, portable X-ray, and CT: patient and operating room personnel radiation exposure in spinal surgery. Spine J. 2014;14(12):2985-91. doi: 10.1016/j.spinee.2014.06.003.

27. Urakov TM. Practical assessment of radiation exposure in spine surgery. World Neurosurg. 2018;120:e752-4. doi: 10.1016/j.wneu.2018.08.158.

28. National Council on Radiation Protection \& Measurements. Limitation of exposure to ionizing radiation: recommendations of the National Council on Radiation Protection and Measurements. Bethesda, MD: National Council on Radiation Protection \& Measurements Report 116;1993. [Internet]. 1993 [accessed 2010 June 18]. Available at: www.ncrp.com/ncrprpts.html. 